\title{
Complete Aortic Endograft Occlusion in a Patient with Psoriasis: A Case Report and Systematic Review of the Literature Seeking for a Potential Causal Association
}

\author{
Vangelis G Alexiou ${ }^{1,2, *}$, Dimitrios Chatzis ${ }^{1}$, Konstantinos G Moulakakis ${ }^{3}$, Stefanos Gkounta ${ }^{4}$, Michail Mitsis ${ }^{4}$, and Stylianos \\ Koutsias $^{1}$
}

${ }^{1}$ Department of Surgery, Vascular Surgery Unit, School of Medicine, University of Ioannina, Ioannina, Greece

${ }^{2}$ Alfa Institute of Biomedical Sciences (AIBS), Athens, Greece

${ }^{3}$ Department of Vascular Surgery, Medical School, National and Kapodistrian University of Athens, Attikon University Hospital, Athens, Greece

${ }^{4}$ Department of Surgery, School of Medicine, University of loannina, loannina, Greece

*Corresponding authors: Vangelis G Alexiou, Department of Surgery, Vascular Surgery Unit, School of Medicine, University of loannina, |Niarxou Avenue, 45500 loannina, Greece, Tel: +30-26510 99694; E-mail: v.alexiou@aibs.gr

Received: 08 Apr, 2021 | Accepted: 04 Jun, 2021 | Published: 14 Jun, 2021

Citation: Alexiou VG, Chatzis D, Moulakakis KG, Gkounta S, Mitsis M, et al. (2021) Complete Aortic Endograft Occlusion in a Patient with Psoriasis: A Case Report and Systematic Review of the Literature Seeking for a Potential Causal Association. J Surg Open Access 7(3): dx.doi.org/10.16966/24700991.242

Copyright: (c) 2021 Alexiou VG, et al. This is an open-access article distributed under the terms of the Creative Commons Attribution License, which permits unrestricted use, distribution, and reproduction in any medium, provided the original author and source are credited.

\begin{abstract}
Background: We report a case of a patient with complete aortic endograft occlusion and no morphological characteristic that could explain this event, other than the hypercoagulant status associated with psoriasis. The patient had severe intertriginous psoriasis complicated with cellulitis and sepsis and was treated with endograft excision and replacement with an aortic tube graft.

Purpose: We sought to identify a potential causal association by performing a systematic literature review on psoriasis related thrombosis.

Main findings: Seven case-control studies between patients with psoriasis and healthy controls examined various aspects of platelet function and morphology. Seven large epidemiological studies provide solid evidence that patients with psoriasis are at high risk for venous thromboembolism. In total, 19 studies were identified associating psoriasis with significant platelet activation, aortic and systemic inflammation, faster arterial thrombotic occlusion, and plaque formation.

Conclusions: It may be reasonable to hypothesize a connection between severe psoriasis and graft thrombosis. This should be taken under consideration when performing major vascular surgery in patients with psoriasis and physicians may need to consider managing these patients as high risk for arterial thrombosis.
\end{abstract}

Keywords: Psoriasis; Arterial thrombosis; Ischemia; Platelet activation; Thromboembolism; Aortic aneurysm

\section{Introduction}

Psoriasis has been involved in the development of Deep Venous Thrombosis (DVT) [1] and has been linked with elevated levels of various cytokines, and interleukins that dramatically promote the platelet aggregation rate [2]. Furthermore, patients with psoriasis are at increased risk for aortic aneurysms [3,4], Acute Coronary Syndrome (ACS) [5], and have global arterial inflammation [6]. However, there has been no report of arterial thrombosis or graft thrombosis associated with psoriasis.

Complete aortic endograft occlusion after Endovascular Aortic Repair (EVAR) is rare and in most cases an apparent cause e.g. iliac artery angulations, iliac perimeter calcification, floating thrombus, severe peripheral arterial disease, or incomplete deployment is present to justify this serious complication [7]. Having recently treated a patient with complete aortic endograft occlusion and no morphological characteristic that could explain the acute thrombosis, other than the hypercoagulant status associated with psoriasis, we decided to report our case and seek a potential causal association by performing a systematic literature review on psoriasis related thrombosis.

\section{Methods}

\section{Case report}

Medical notes, including emergency department admission notes, operative notes, medical charts, imaging, lab tests, microbiological testing, drug charts, and follow up notes were retrieved and studied to describe the case in detail.

\section{Systematic literature review}

Search strategy: To identify relevant studies, we systematically searched PubMed (until November 2020) using the following search 
pattern: psoriasis and (thrombosis or DVT or platelets or thrombus or clotting or thromboembolism or acute ischemia or graft thrombosis or aortic inflammation). No limitation on the year of publication or language was set. Furthermore, the references in the relevant articles, including review studies, were checked to identify additional resources. Abstracts of conference proceedings were not sought.

Inclusion criteria: Two of the authors (VGA and DC) independently performed the literature search to locate potentially eligible studies. All studies, including reviews, epidemiological and laboratory studies, case reports and case series, reporting on the relation of psoriasis with venous or arterial thrombosis and coagulation disorders were retrieved.

Data extraction: The following data were extracted from all eligible articles: first author, year of publication, type of study, main outcomes and conclusions. The most important findings were tabulated.

The study adheres to the Preferred Reporting Items for Systematic Reviews and Meta-Analyses (PRISMA) guidelines [8].

\section{Case Report}

A 62 year old male patient was transferred to our department from a small rural hospital with acute bilateral lower limp ischemia. Six months prior to this admission the patient had been submitted to Endovascular Aortic Repair (EVAR) for a $5.5 \mathrm{~cm}$ infrarenal abdominal aortic aneurysm. There was endograft thrombosis and occlusion extending from the main body to both limps of the endograft (Cook Zenith AAA Endovascular Graft). It should be noted that both on the CT scan that was performed on admission (Image 1) and the one month post-EVAR follow-up CT scan, there was no morphological characteristic that could explain the acute thrombosis eg., iliac artery angulations, iliac perimeter calcification, floating thrombus, severe peripheral arterial disease, or incomplete deployment.

Unfortunately, this was a late presentation as the time taken by the referring doctors to establish diagnosis was more than 15 days. The patient had already developed wet gangrene and severe neurological deficit of his right foot with ischemic skin extending to mid-calf. The left lower limp was also ischemic with rest pain but viable.

The patient had a history of psoriasis and his right groin area had developed inverse (intertriginous) psoriasis. The groin skin fold on the right had acutely developed a 5 by $15 \mathrm{~cm}$ ulceration complicated with fungal infection and exacerbated by ischemia. There was cellulitis and local sepsis, white cells count (WCC) was 17.5 109/L (normal range 4-11 109/L) and Neutrophils 13.3 109/L (normal range 2.0-7.5 109/L). This did not involve the femoral incision that was performed for EVAR deployment but restricted the surgical option for an extranatomical bypass (axillofemoral bypass) to revascularise the limp. The patient was afebrile. Dermatology consultation and advice was sought and treatment with broad spectrum antimicrobial (4g piperacillin/0.5g Tazobactam administered IV every 6 hours and Vancomycin $1 \mathrm{~g}$ administered IV every 12hours) and antifungal (400mg IV Fluconazole administered IV once daily) was immediately initiated. The cultures taken from the groin ulceration grew dermatophytes. Coagulation tests including prothrombin time, platelet count, activated partial thromboplastin time, and fibrinogen were within normal range. However, tests that are associated with platelet activation were higher than normal; Platelet Distribution Width (PDW) was $19.4 \%$ (normal range 9-17\%) and Mean Platelet Volume (MPV) was $13.2 \mathrm{Fl}$
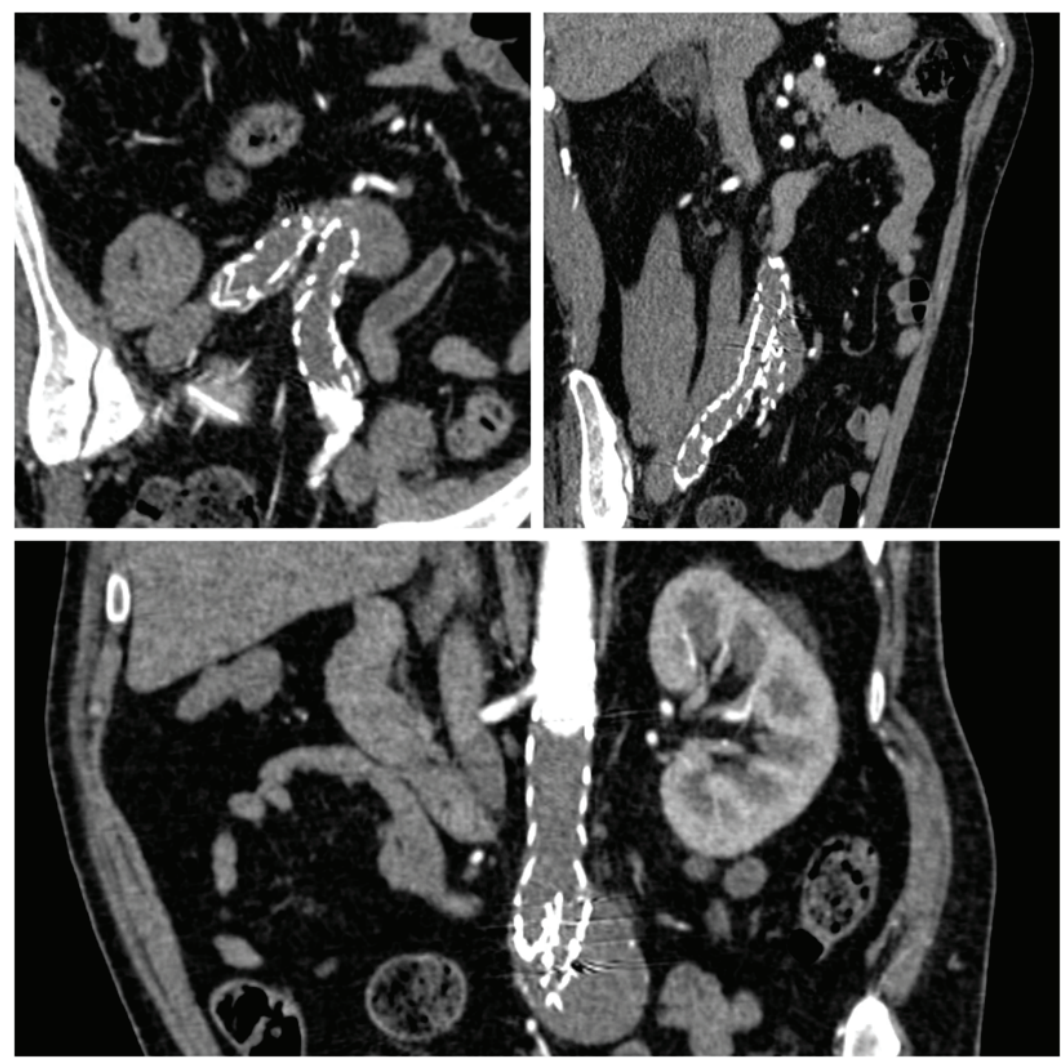

Image 1: Endograft thrombosis and occlusion extending from the main body to both limps of the endograft (Cook Zenith AAA Endovascular Graft).

Citation:Alexiou VG, Chatzis D, Moulakakis KG, Gkounta S, Mitsis M, et al. (2021) Complete Aortic Endograft Occlusion in a Patient with Psoriasis: A Case Report and Systematic Review of the Literature Seeking for a Potential Causal Association. J Surg Open Access 7(3): dx.doi. org/10.16966/2470-0991.242 
(normal range 7-11 Fl). The patient was not on any active treatment for the psoriasis, including Disease-Modifying Antirheumatic Drugs (DMARDs). The Psoriasis Area Severity Index (PASI) was 13.8. He was on Aspirin 100mg once daily, was a smoker, and had nothing else of note in his past medical history.

The surgical plan involved above knee amputation of the right limp, excision of the endograft and replacement with a tube graft. The patient was informed in detail about the risks and benefits of the procedure and refused amputation despite having been explained the detrimental effects of revascularising a potentially non-viable limp. $\mathrm{He}$ was also informed and consented to include the details of his case in scientific research and publication.

A middle line abdominal incision was performed and the aortic neck was dissected to obtain control both below and above the renal arteries. The iliac arteries were also dissected to the level of their bifurcation. The aneurysm sac was opened and the endograft limps were forcefully retracted (Image 2a) and detached from their anchoring points in the common iliac arteries. Thrombectomies were performed distally and back flow from both limps was successfully established. The endograft main body was cut and removed leaving intact the suprarenal fixation and a $2 \mathrm{~cm}$ length of the endograft fabric to permit a safe anastomosis. Impressively, the thrombus plug in the part of the graft that was left behind could withhold the force of the aortic pulsation without the need to clamp the aorta at a higher level (Image 2b). Proximal aortic thrombectomy was performed and an aortic clamp was applied on the endograft fixation points just below the renal arteries. A $20 \mathrm{~mm}$ tube graft was placed proximally oversewing the endograft fabric and native aortic neck wall and distally on the aortic bifurcation (Image 2c). Initial attempt to restore blood flow ended in acute thrombosis of the new tube graft and iliac arteries. Incomplete thrombectomies and/ or a hypercoagualant state associated with psoriasis maybe have been the reason for this. Thrombectomies were performed again proximally and distally in the aorta and iliac vessels. Flow was successfully restored this time with pulsation present at the level of both femoral arteries. Additional distal thrombectomies were done via a femoral cut-down on the left. The operation was otherwise uneventful with minimal blood loss and, at closure, the small bowel and colon appeared healthy and well perfused. The patient was transferred to the Intensive Care Unit (ICU). Unfortunately, within few hours the patient deteriorated developing lactate acidosis and severe haemodynamic instability and died 24 hours after the operation. This outcome may be largely attributed to a severe revascularisation syndrome caused by restoring blood flow to the non-viable right limp.

\section{Systematic literature review}

Literature review: In figure 1, we present a flow diagram describing the selection process followed to identify reports included in this systematic review. The PubMed search yielded 433 potentially relevant articles; after studying the title, abstracts, and full texts, 19 studies fulfilled the inclusion criteria for this systematic review

In table 1 , we present the characteristics and outcomes of the reviewed papers. Seven case-control studies between patients with

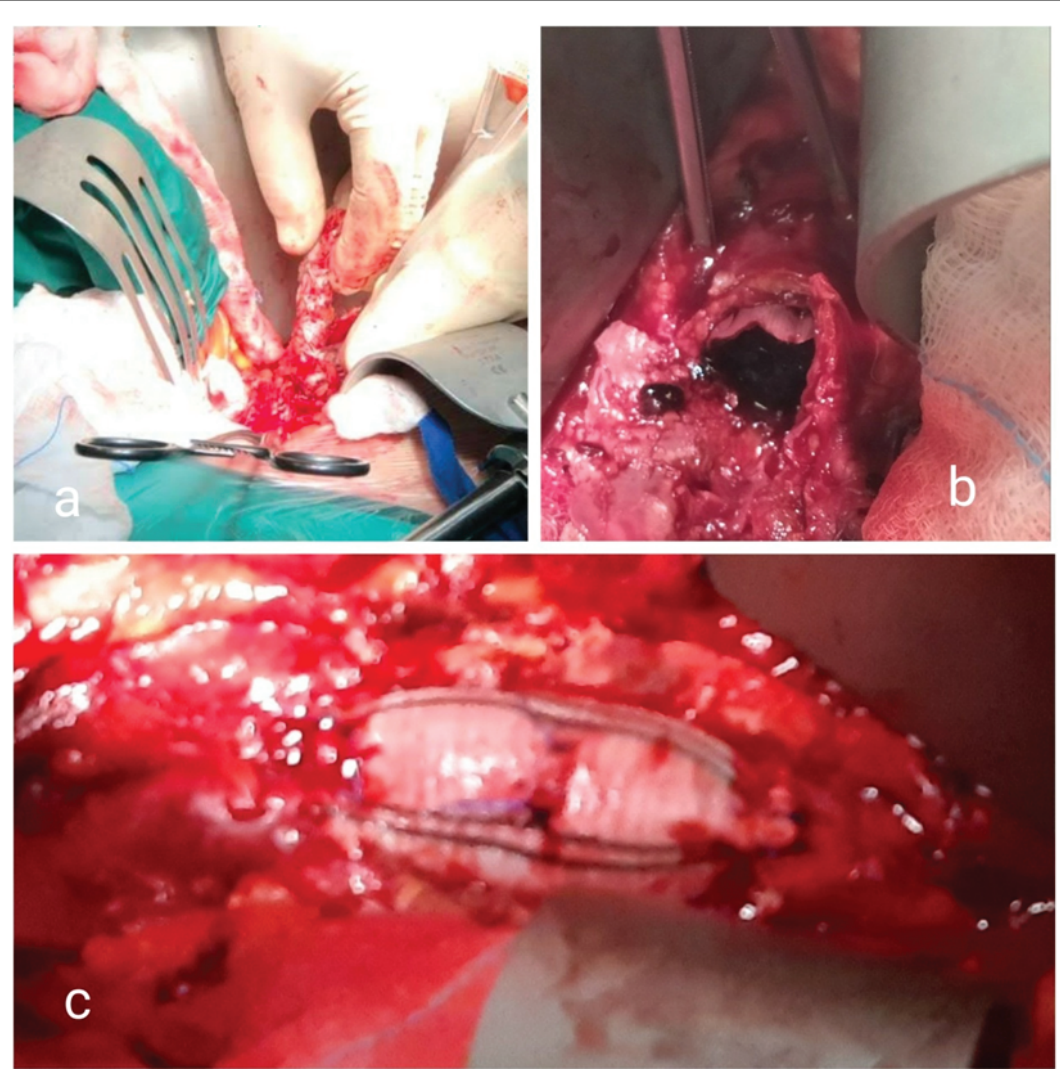

Image 2a: Detached endograft limps.

2b: Endograft main body cut and removed leaving intact the suprarenal fixation and a $2 \mathrm{~cm}$ length of the endograft fabric. The thrombus plug can withhold the force of the aortic pulsation without the need to clamp the aorta.

2c: $20 \mathrm{~mm}$ tube graft was placed proximally over sewing the endograft fabric and native aortic neck wall and distally on the aortic bifurcation. 


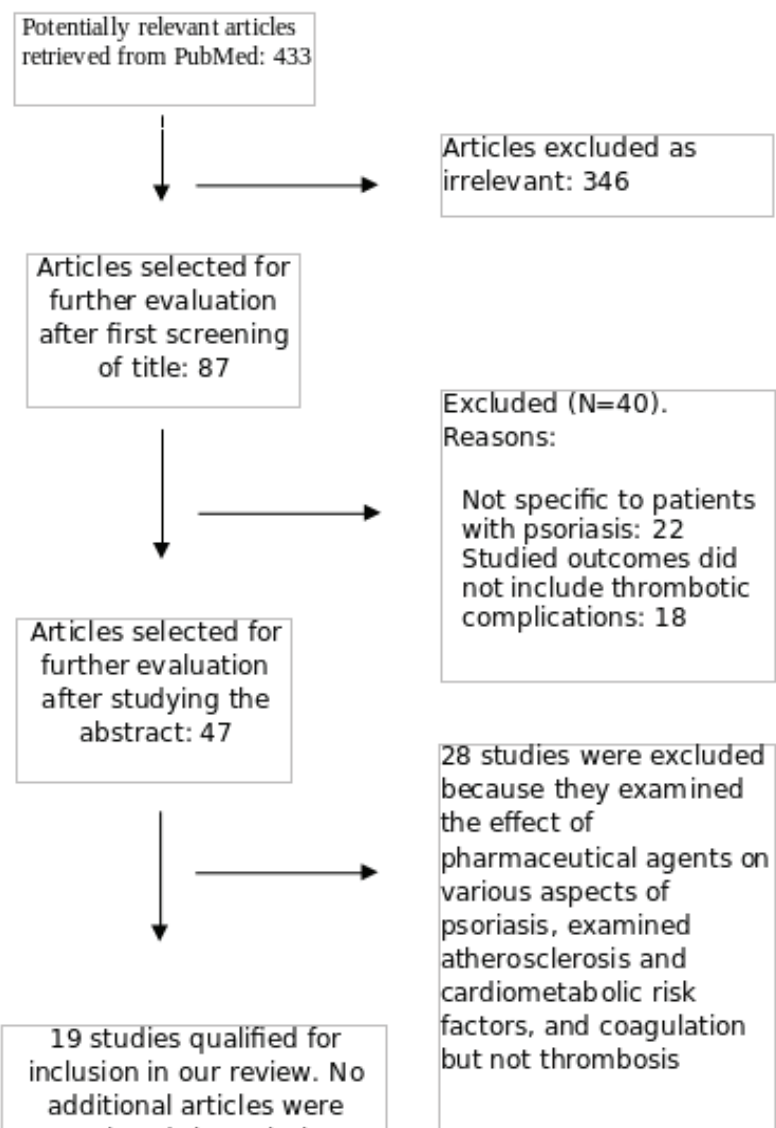

additional aticles were

retrieved through the

references of the above.

Figure 1: Flow diagram of the reviewed studies.

psoriasis and healthy controls examined various aspects of platelet function and morphology including Mean Platelet Volume (MPV), Platelet Mass Index (PMI) [9,10], distribution width, p-selectin concentrations [2,11], platelet aggregation [2], light transmition aggregometry as index of platelet reactivity [12], plasma levels of beta-thromboglobulin (beta-TG), Platelet Factor 4 (PF4) [13], and Platelet-Derived Microparticles (PDMPs) [11] as markers of platelet activation. All of the above studies concluded that there is evidence of platelet activation in psoriasis causing higher plaque formation [9], global arterial inflammation [2,6], and abnormally high platelet reactivity [12]. Mean platelet volume levels are increased in patients with psoriasis [10] and this may be a marker of the severity. Patients with extensive disease are at higher risk of having platelet dysfunction [11].

Seven large epidemiological studies from Korea [14], Taiwan [15], Sweden [5], USA [16,17], Denmark [18,19], and a meta-analysis [1] of some of the above studies provide solid evidence that patients with psoriasis are at high risk for VTE. Furthermore, we have identified 2 experimental mouse model studies that have associated psoriasis with arterial thrombotic occlusion [20] and with aortic root inflammation and thrombosis [21]. Finally, 2 cases-reports [22,23] were also included in this systematic review pointing to the need of clinical awareness of occurrence of thrombosis and pulmonary embolism in patients with psoriasis.

\section{Discussion and Conclusion}

This case of aortic endograft occlusion is, to our knowledge, the first report of arterial graft thrombosis in patients with psoriasis. It should be noted that it was impossible to identify any other known cause of endograft occlusion including more than $15 \%$ oversized endograft in iliac arteries with iliac artery angulation $\geq 60^{\circ}$ and iliac perimeter calcification $\geq 50 \% 7$. The patient had at the time of presentation severe (intertriginous) psoriasis complicated with cellulitis and local sepsis. The iliac artery occlusion caused ischemia of the groin area and may have exacerbated the desquamation of the inguinal crease leading to infection and severe tissue loss. The fact that the right iliofemoral area was heavily contaminated precluded the option of an axillofemoral bypass. We had to keep the new graft away from the infected area and thus, decided to replace the endograft with a straight tube graft.

Patients with extensive psoriasis are at higher risk of acute thrombotic events [13] and this may have happened in this case. Impressively, the new aortic graft also thrombosed few seconds after restoring circulation indicating that the patient was in a hypercoagulable state. In retrospect, the choice to revascularise a potentially non-viable limp should have been avoided. Furthermore, a more aggressive treatment for psoriasis prior to the operation may have been of benefit including DMARDs. There is evidence that patients with well controlled psoriasis have lower risk for thrombotic events compared to patients with poorly controlled disease [16]. In fact, the risk for VTE in patients 
Table 1: Main characteristics, outcomes, and results of studies included in the systematic review.

\begin{tabular}{|c|c|c|c|c|c|}
\hline $\begin{array}{l}\text { First Author/ } \\
\text { Reference }\end{array}$ & $\begin{array}{c}\text { Year of } \\
\text { publication }\end{array}$ & Country & Study design and population & Studied Outcomes & Results/conclusions \\
\hline Unal M [8] & 2016 & Turkey & $\begin{array}{c}\text { Comparative study between } 320 \\
\text { patients with psoriasis and } 200 \\
\text { healthy controls }\end{array}$ & $\begin{array}{c}\text { Mean platelet volume } \\
\text { (MPV), Platelet mass } \\
\text { index (PMI), ESR and CRP }\end{array}$ & $\begin{array}{l}\text { Higher PMI and MPV values, which } \\
\text { mean higher plaque formation capacity } \\
\text { and more active platelets, in psoriasis } \\
\text { may make psoriasis patients more } \\
\text { sensitive to atherosclerotic plaque } \\
\text { formation and complications. }\end{array}$ \\
\hline Rhee TM, et al. [13] & 2017 & Korea & $\begin{array}{c}\text { Cross-sectional study with } \\
\text { data from National Insurance } \\
\text { service registry. } 13,385 \text { psoriasis } \\
\text { patients }(1,947 \text { with severe } \\
\text { psoriasis) }\end{array}$ & $\begin{array}{c}\text { Risk of atrial fibrillation } \\
(\mathrm{AF}) \text { and thromboembolic } \\
\text { events (TE) }\end{array}$ & $\begin{array}{l}\text { Severe, but not mild, psoriasis } \\
\text { significantly increased AF and TE risk. }\end{array}$ \\
\hline Chung WS, et al. [15] & 2017 & Taiwan & \begin{tabular}{|} 
Matched case-control study \\
with data drawn from National \\
Health Database. 8945 patients \\
with psoriasis and 8945 controls
\end{tabular} & $\begin{array}{l}\text { Incidence of venous } \\
\text { thromboembolism (VTE) }\end{array}$ & $\begin{array}{c}\text { After adjustment for covariates, the } \\
\text { patients with psoriasis presented a } \\
2.02 \text {-fold risk of VTE }\end{array}$ \\
\hline Bengtsson $\mathrm{K}$, et al. [5] & 2017 & Sweden & $\begin{array}{c}\text { Prospective nationwide cohort } \\
\text { study that included } 16,063 \\
\text { patients with psoriatic arthritis } \\
\text { and } 266,435 \text { general population } \\
\text { controls }\end{array}$ & $\begin{array}{l}\text { Risk for acute coronary } \\
\text { syndrome (ACS), stroke } \\
\text { and VTE }\end{array}$ & $\begin{array}{l}\text { Patients with psoriaic arthritis are at } \\
\text { increased risk for ACS. stroke events, } \\
\text { and VTE. For VTE the age-and sex- } \\
\text { adjusted HRs were increased about } \\
50 \% \text { compared to GP. }\end{array}$ \\
\hline Ogdie A, et al. [16] & 2018 & USA & $\begin{array}{c}\text { Cohort study in a primary care } \\
\text { medical record database. } 12,084 \\
\text { patients with psoriatic arthritis, } \\
\text { and } 194,288 \text { with psoriasis and } \\
\text { controls ( } n=1225571 \text { ). }\end{array}$ & $\begin{array}{l}\text { VTE defined as the } \\
\text { combined endpoint } \\
\text { of Deep Venous } \\
\text { Thrombosis (DVT) and } \\
\text { Pulmonary Embolism } \\
\text { (PE). Interaction with } \\
\text { Disease Modifying } \\
\text { Anti-Rheumatic Drugs } \\
\text { (DMARD) }\end{array}$ & $\begin{array}{l}\text { Patients with RA (with and without } \\
\text { a DMARD prescription) and patients } \\
\text { with mild psoriasis had significantly } \\
\text { elevated risks of VTE (HR 1.35, 1.29, } \\
\text { and } 1.07 \text {, respectively). Severe } \\
\text { psoriasis and PsA prescribed a DMARD } \\
\text { had an elevated but not statistically } \\
\text { significant risk for VTE. }\end{array}$ \\
\hline Hjuler KF, et al. [6] & 2017 & Denmark & $\begin{array}{l}\text { Observational, controlled clinical } \\
\text { study including patients with } \\
\text { psoriasis ( } n=12 \text { ) and matched } \\
\text { controls }(n=23)\end{array}$ & $\begin{array}{l}\text { Arterial inflammation } \\
\text { assessed by } 18 \\
\text { F-fluorodeoxyglucose } \\
\text { (FDG) positron emission } \\
\text { tomography-computed } \\
\text { tomography }\end{array}$ & $\begin{array}{l}\text { Global arterial inflammation and } \\
\text { subcutaneous inflammation were } \\
\text { significantly increased in patients } \\
\text { with moderate-to-severe psoriasis } \\
\text { compared with controls. (mean } \pm \text { SD } \\
\text { whole vessel TBR max } 2.46 \pm 0.31 \text { vs. } \\
2.09 \pm 0.36 ; P=0.005 \text { ) }\end{array}$ \\
\hline $\begin{array}{l}\text { Chandrashekar } L \text {, et } \\
\text { al. [2] }\end{array}$ & 2015 & India & $\begin{array}{l}\text { Cross-sectional matched case } \\
\text { control study- } 62 \text { patients with } \\
\text { psoriasis and } 62 \text { controls. }\end{array}$ & \begin{tabular}{|} 
Mean Platelet Volume \\
(MPV) and Platelet \\
Distribution Width \\
(PDW)], P-selectin \\
and Platelet Derived \\
Microparticle (PDMP), \\
high sensitivity C-reactive \\
Protein (hs-CRP), \\
Interleukin (IL)-6
\end{tabular} & $\begin{array}{l}\text { Significant platelet activation and } \\
\text { systemic inflammation were observed } \\
\text { in patients with psoriasis, especially } \\
\text { when associated with severe disease. }\end{array}$ \\
\hline Ahlehoff O, et al. [19] & 2015 & USA & $\begin{array}{l}\text { Experimental mouse } \\
\text { model study to determine } \\
\text { whether chronic skin-specific } \\
\text { inflammation was sufficient } \\
\text { to promote thrombosis. Case } \\
\text { control study between mice } \\
\text { with acute (C57BI/6 } n=25 \text { )and } \\
\text { chronic (K5-IL-17C } n=14 \text { ) skin } \\
\text { inflammation and controls ( } n=21 \\
\text { for both groups) }\end{array}$ & $\begin{array}{l}\text { Arterial thrombosis was } \\
\text { induced using carotid } \\
\text { artery photochemical } \\
\text { injury and carotid } \\
\text { artery diameters were } \\
\text { measured post-clot } \\
\text { formation. Measures of } \\
\text { clot formation including } \\
\text { Prothrombin (PT) } \\
\text { and activated Partial } \\
\text { Thromboplastin Time } \\
\text { (aPTT) }\end{array}$ & $\begin{array}{l}\text { Chronic, but not acute, skin-specific } \\
\text { inflammation was associated with } \\
\text { faster arterial thrombotic occlusion }\end{array}$ \\
\hline
\end{tabular}




\begin{tabular}{|c|c|c|c|c|c|}
\hline $\begin{array}{l}\text { Yudhishdran JM, et } \\
\text { al. [22] }\end{array}$ & 2015 & Sri Lanka & Case report & $\begin{array}{l}\text { Clinical report of a } \\
\text { patient psoriasis and } \\
\text { chronic portal vein } \\
\text { thrombosis with } \\
\text { cavernous transformation }\end{array}$ & $\begin{array}{l}\text { Clinical awareness of occurrence of } \\
\text { thrombosis in patients with psoriasis. }\end{array}$ \\
\hline Ahlehoff O, et al. [19] & 2015 & Denmark & \begin{tabular}{|} 
Nationwide cohort study. Danish \\
patients hospitalized with \\
nonvalvular atrial fibrillation \\
in the period $1997-2011$ \\
( $\mathrm{n}=99,357)$ excluded subjects \\
treated with anticoagulation
\end{tabular} & $\begin{array}{l}\text { Hospitalization or death } \\
\text { from thromboembolism } \\
\text { in patients with psoriasis }\end{array}$ & $\begin{array}{l}\text { In patients with nonvalvular atrial } \\
\text { fibrillation not treated with oral } \\
\text { anticoagulation, severe psoriasis } \\
\text { was associated with increased risk of } \\
\text { thromboembolism. }\end{array}$ \\
\hline Ungprasert $\mathrm{P}$, et al. [1] & 2014 & USA & $\begin{array}{c}\text { Meta-analysis of observational } \\
\text { studies that reported VTE risk in } \\
\text { patients with psoriasis vs. non- } \\
\text { psoriasis participants. }\end{array}$ & $\begin{array}{l}\text { Odds ratio, relative } \\
\text { risk, hazard ratio or } \\
\text { standardized incidence } \\
\text { ratio for VTE }\end{array}$ & $\begin{array}{l}\text { Pooled results from } 4 \text { studies and } \\
\text { patients. The risk ratio of VTE in } \\
\text { patients with psoriasis was } 1.46 \text { ( } 95 \% \\
\qquad \mathrm{Cl}, 1.29-1.66) \text {. }\end{array}$ \\
\hline Wang Y, et al. [20] & 2012 & USA & $\begin{array}{c}\text { Murine model of psoriasiform } \\
\text { skin disease }(n=18) \text { compared to } \\
\text { controls }(n=19)\end{array}$ & $\begin{array}{c}\text { Accumulation of } \\
\text { macrophages, } T \\
\text { lymphocytes, and B } \\
\text { lymphocytes, necrosis } \\
\text { factor- } \alpha \text {, IL-17A, vascular } \\
\text { endothelial growth } \\
\text { factor, IL-12, monocyte } \\
\text { chemotactic protein-1, } \\
\text { and S100A8/A9, as well } \\
\text { as splenic and circulating } \\
\text { CD11b(+)Ly- } 6 C \text { (hi) pro- } \\
\text { inflammatory monocytes }\end{array}$ & $\begin{array}{l}\text { Skin-specific inflammation promotes } \\
\text { aortic root inflammation and } \\
\text { thrombosis }\end{array}$ \\
\hline Ko JH, et al. [21] & 2011 & Taiwan & Case report & $\begin{array}{c}\text { Clinical report of a } 42 y \\
\text { old patient with psoriasis } \\
\text { and acute pulmonary } \\
\text { embolism }\end{array}$ & $\begin{array}{c}\text { Severe psoriasis can be associated with } \\
\text { eosinophilia and metabolic syndrome, } \\
\text { acute pulmonary embolism }\end{array}$ \\
\hline Lutsey PL, et al. [16] & 2012 & USA & $\begin{array}{c}\text { Cohort drawn from The lowa } \\
\text { Women's Health Study (38,608 } \\
\text { women who were followed for a } \\
\text { median of } 11.3 \text { years) }\end{array}$ & $\begin{array}{c}\text { Incidence of VTE events } \\
\text { and age-adjusted hazard } \\
\text { ratio (HR) for VTE. HR } \\
1.40(95 \% \mathrm{Cl}: 1.00,1.94) \\
\text { patients with psoriasis } \\
\text { versus controls }\end{array}$ & $\begin{array}{l}\text { There is a relation between chronic, } \\
\text { systemic inflammation and risk of VTE, } \\
\text { and suggests that patients with even } \\
\text { mild-to-moderate psoriasis may be at } \\
\text { elevated risk of a VTE event. }\end{array}$ \\
\hline $\begin{array}{l}\text { Di Minno MN, et al. } \\
\text { [11] }\end{array}$ & 2012 & Itay & $\begin{array}{c}\text { Case control study. Individuals } \\
\text { with psoriatic arthritis receiving } \\
\text { tumor necrosis factor- } \alpha \text { (TNF- } \alpha) \\
\text { blockers }(n=114) \text { and healthy } \\
\text { controls }(n=114) \text { matched for } \\
\text { age, sex, and cardiovascular risk } \\
\text { factors }\end{array}$ & $\begin{array}{l}\text { Light transmission } \\
\text { aggregometry }\end{array}$ & $\begin{array}{l}\text { Subjects with active psoriatic arthritis } \\
\text { had abnormally high platelet reactivity }\end{array}$ \\
\hline Ahlehoff O, et al. [18] & 2011 & Denmark & $\begin{array}{l}\text { National cohort study with } \\
35,138 \text { patients with mild and } \\
3,526 \text { patients with severe } \\
\text { psoriasis were identified and } \\
\text { compared with } 4,126,075 \\
\text { controls }\end{array}$ & Risk for VTE & $\begin{array}{l}\text { Patients with psoriasis are at increased } \\
\text { risk of VTE. The risk was highest in } \\
\text { young patients with severe psoriasis. } \\
\text { The rate ratio (RR) of VTE was elevated } \\
\text { in all patients with psoriasis with RR } \\
1.35(95 \% \text { confidence interval }[\mathrm{Cl}] 1.21 \text { - } \\
1.49 \text { ) and RR } 2.06 \text { (Cl 1.63-2.61) for } \\
\text { mild and severe psoriasis, respectively. }\end{array}$ \\
\hline Canpolat F, et al. [9] & 2010 & Turkey & $\begin{array}{l}\text { Case-control study comparing } \\
106 \text { patients with psoriasis } \\
\text { (48 with psoriatic arthritis and } \\
58 \text { without) and } 95 \text { healthy } \\
\text { controls. }\end{array}$ & Mean platelet volume & $\begin{array}{l}\text { MPV in patients with psoriasis } 8.7 \pm 0.9 \\
\mathrm{fL} \text { was significantly higher than that of } \\
\text { control subjects } 7.3 \pm 0.8 \mathrm{fL}(p<0.001) \text {. } \\
\text { There was also statistical difference } \\
\text { between MPV levels of patients with } \\
(9.5 \pm 0.8) \text { and without }(8.0 \pm 0.7) \\
\text { arthritis ( } p<0.001) \text {. } \\
\text { MPV levels are increased in patients } \\
\text { with psoriasis and PsA. MPV may be a } \\
\text { marker for the severity of psoriasis. }\end{array}$ \\
\hline
\end{tabular}




\begin{tabular}{|c|c|c|c|c|c|}
\hline $\begin{array}{l}\text { Tamagawa-Mineoka } \\
\text { R, et al. [10] }\end{array}$ & 2010 & Japan & $\begin{array}{c}\text { Case-control study in } 21 \text { patients } \\
\text { with psoriasis and } 22 \text { healthy } \\
\text { control subjects }\end{array}$ & $\begin{array}{c}\text { Plasma Levels of Platelet- } \\
\text { Derived Microparticles } \\
\text { (PDMPs) and soluble } \\
\text { P-selectin }\end{array}$ & $\begin{array}{l}\text { Plasma PDMPs and soluble P-selectin } \\
\text { levels were markedly higher in patients } \\
\text { with psoriasis compared with those in } \\
\text { healthy control subjects. } \\
\text { Blood platelets are activated in } \\
\text { patients with psoriasis, especially in } \\
\text { those with extensive disease }\end{array}$ \\
\hline $\begin{array}{l}\text { Tamagawa-Mineoka } \\
\text { R, et al. [13] }\end{array}$ & 2008 & Japan & $\begin{array}{c}\text { Case control study with } 22 \\
\text { healthy control and } 16 \text { patients } \\
\text { with psoriasis }\end{array}$ & $\begin{array}{l}\text { Plasma levels of beta- } \\
\text { thromboglobulin (beta- } \\
\text { TG) and Platelet Factor } \\
4 \text { (PF4) as platelet } \\
\text { activation markers }\end{array}$ & $\begin{array}{l}\text { Blood platelets are activated in } \\
\text { patients with psoriasis }\end{array}$ \\
\hline
\end{tabular}

with severe psoriasis and Psoriatic Arthritis (PsA) who are prescribed a DMARD, does not differ significantly to healthy controls [16].

The systematic literature review provides evidence to support that patients with psoriasis are at increased risk for ACS, stroke events, and VTE. Furthermore, the reviewed studies have associated psoriasis with significant platelet activation, aortic and systemic inflammation, faster arterial thrombotic occlusion in mouse models, and plaque formation. The major limitation of this systematic review is that the available studies have methodological heterogeneity that does not permit any meaningful statistical analysis. In our patient MPV and PDW that are associated with platelet activation were abnormally high. Based on the above evidence, it is reasonable in our case; to at least hypothesize that there may be a causal association between severe psoriasis and the event of complete aortic endograft occlusion. One should take this under consideration when performing major vascular surgery in patients with psoriasis and consider managing these patients as high risk for arterial thrombosis; including administering oral anticoagulation and/ or double antiplatelet therapy, and performing more frequent duplex ultrasound follow-up for patency issues.

\section{Disclosure Statement}

All authors have no conflict of interest to disclose.

\section{Authors Contribution}

VGA conceived and drafted the manuscript. VGA and DC performed the systematic review. KGM, SG, MM, DC, and SK contributed to the final version of the manuscript. SK and KGM supervised the project. SK passed away after completion and submission of this manuscript.

\section{References}

1. Ungprasert P, Sanguankeo A, Upala S, Suksaranjit P (2014) Psoriasis and risk of venous thromboembolism: a systematic review and meta-analysis. QJM 107: 793-797.

2. Chandrashekar L, Rajappa M, Revathy G, Sundar I, Munisamy M, et al. (2015) Is enhanced platelet activation the missing link leading to increased cardiovascular risk in psoriasis? Clin Chim Acta 446: 181185.

3. Chiu HY, Lo PC, Huang WF, Tsai YW, Tsai TF (2016) Increased risk of aortic aneurysm (AA) in relation to the severity of psoriasis: A national population-based matched-cohort study. J Am Acad Dermatol 75: 747-754.

4. Khalid U, Ahlehoff O, Gislason GH, Skov L, Torp-Pedersen C, et al. (2015) Increased risk of aortic valve stenosis in patients with psoriasis: a nationwide cohort study. Eur Hear J 36: 2177-2183.
5. Bengtsson $K$, Forsblad-d'Elia $H$, Lie $E$, Klingberg $E$, Dehlin $M$, et al. (2017) Are ankylosing spondylitis, psoriatic arthritis and undifferentiated spondyloarthritis associated with an increased risk of cardiovascular events? A prospective nationwide populationbased cohort study. Arthritis Res Ther 19: 102.

6. Hjuler KF, Gormsen LC, Vendelbo MH, Egeberg A, Nielsen J, et al. (2017) Increased global arterial and subcutaneous adipose tissue inflammation in patients with moderate-to-severe psoriasis. $\mathrm{Br} \mathrm{J}$ Dermatol 176: 732-740.

7. Moulakakis KG, Antonopoulos CN, Klonaris C, Kakisis J, Lazaris AM, et al. (2018) Bilateral Endograft Limb Occlusion after Endovascular Aortic Repair: Predictive Factors of Occurrence. Ann Vasc Surg 46: 299-306.

8. Moher D, Liberati A, Tetzlaff J, Altman DG; PRISMA Group (2010) Preferred reporting items for systematic reviews and meta-analyses: the PRISMA statement. Open Med 3: e123-30.

9. Unal M (2016) Platelet mass index is increased in psoriasis. A possible link between psoriasis and atherosclerosis. Arch Med Sci Atheroscler Dis 1: e145-e149.

10. Canpolat F, Akpinar H, Eskioglu F (2010) Mean platelet volume in psoriasis and psoriatic arthritis. Clin Rheumatol 29: 325-328.

11. Tamagawa-Mineoka R, Katoh N, Kishimoto S (2010) Platelet activation in patients with psoriasis: increased plasma levels of platelet-derived microparticles and soluble P-selectin. J Am Acad Dermatol 62: 621-626.

12. Di Minno MN, lervolino S, Peluso R, Scarpa R, Di Minno G (2012) Platelet reactivity and disease activity in subjects with psoriatic arthritis. J Rheumatol 39: 334-336.

13. Tamagawa-Mineoka R, Katoh $\mathrm{N}$, Ueda E, Masuda K, Kishimoto $\mathrm{S}$ (2008) Elevated platelet activation in patients with atopic dermatitis and psoriasis: increased plasma levels of beta-thromboglobulin and platelet factor 4. Allergol Int 57: 391-396.

14. Rhee TM, Lee JH, Choi EK, Han KD, Lee H, et al. (2017) Increased Risk of Atrial Fibrillation and Thromboembolism in Patients with Severe Psoriasis: a Nationwide Population-based Study. Sci Rep 7: 9973.

15. Chung WS, Lin CL (2017) Increased risks of venous thromboembolism in patients with psoriasis. A Nationwide Cohort Study. Thromb Haemost 117: 1637-1643.

16. Ogdie A, Kay McGill N, Shin DB, Takeshita J, Jon Love T, et al. (2018) Risk of venous thromboembolism in patients with psoriatic arthritis, psoriasis and rheumatoid arthritis: a general population-based cohort study. Eur Heart J 39: 3608-3614. 
17. Lutsey PL, Prizment AE, Folsom AR (2012) Psoriasis is associated with a greater risk of incident venous thromboembolism: the lowa Women's Health Study. J Thromb Haemost 10: 708-711.

18. Ahlehoff $\mathrm{O}$, Gislason $\mathrm{G}$, Lamberts $\mathrm{M}$, Folke F, Lindhardsen J, et al. (2015) Risk of thromboembolism and fatal stroke in patients with psoriasis and nonvalvular atrial fibrillation: a Danish nationwide cohort study. J Intern Med 277: 447-455.

19. Ahlehoff $\mathrm{O}$, Gislason $\mathrm{GH}$, Lindhardsen J, Charlot MG, Jørgensen $\mathrm{CH}$, et al. (2011) Psoriasis carries an increased risk of venous thromboembolism: a Danish nationwide cohort study. PLoS One 6: e18125.
20. Golden JB, Wang Y, Fritz Y, Diaconu D, Zhang X, et al. (2015) Chronic, not acute, skin-specific inflammation promotes thrombosis in psoriasis murine models. J Transl Med 13: 382.

21. Wang Y, Gao H, Loyd CM, Fu W, Diaconu D, et al. (2012) Chronic skin-specific inflammation promotes vascular inflammation and thrombosis. J Invest Dermatol 132: 2067-2075.

22. Ko JH, Lin JW, Hui RC (2011) Acute pulmonary embolism in a patient with hypereosinophilia and psoriasis. Chang Gung Med J 34: 17-23.

23. Yudhishdran JM, Navinan R, Jeyalakshmy S, Ratnatilaka A (2015) Portal vein thrombosis associated with psoriasis: a case report. BMC Res Notes 8: 87. 